\title{
Physiological quality of soybean seeds produced in four edaphoclimatic regions of Santa Catarina ${ }^{1}$
}

\author{
Volmir Frandoloso ${ }^{2}$, Géri Eduardo Meneghello³, Maria Ângela André3, \\ Cristiane Deuner ${ }^{3 *}$, Winicius Menegaz ${ }^{4}$
}

\begin{abstract}
The production of soybeans in the state of Santa Catarina is quite significant in the national context, since the state is recognized for producing seeds with high standards of physiological quality, due to the use of modern technologies and favorable climatic conditions. The aim of this study was to evaluate the physiological quality of soybean seeds produced by major companies in the state of Santa Catarina, analyzed in three seasons: harvesting (reception at UBS), after processing and at the time of sale. The experiment was conducted in the state of Santa Catarina, in the main regions and companies producing commercial soybean seeds: Xanxerê (companies A, B and C), Abelardo Luz (companies D and E), and Campus Novos (companies F and G), in addition to Canoinhas, which was evaluated with a single producer (company H). Data analysis and interpretation of the results showed that the soybean seeds produced in different regions have adequate quality for sowing and germination within the standards required for marketing, except the BRS 295 cultivars and Don Mario 7.0i company "F".
\end{abstract}

Index terms: Glycine max (L.) Merrill, vigor, harvest, beneficiation, commercialization.

\section{Qualidade fisiológica de sementes de soja produzidas em quatro regiões edafoclimáticas de Santa Catarina}

\begin{abstract}
RESUMO - A produção de sementes de soja no estado de Santa Catarina é bastante significativa no contexto nacional, sendo o estado reconhecido por produzir sementes com altos padrões de qualidade fisiológica, o que se deve ao uso de tecnologias modernas e adequadas, aliado às condições climáticas favoráveis. O objetivo deste trabalho foi avaliar a qualidade fisiológica de sementes de soja produzidas pelas principais empresas do estado de Santa Catarina, analisadas em três épocas: colheita (recepção na UBS), após o beneficiamento e no momento da comercialização. O experimento foi conduzido nas principais regiões e empresas produtoras de sementes de soja comercial do estado, na safra 2009/10: Xanxerê (Empresas A, B e C), Abelardo Luz (Empresas D e E), Campos Novos (Empresas F e G) e em Canoinhas (Empresa H). A análise dos dados e a interpretação dos resultados permitiu concluir que as sementes de soja produzidas nas diferentes regiões apresentam qualidade adequada para a semeadura, com germinação dentro dos padrões exigidos para comercialização, exceto as cultivares BRS 295 e Don Mario 7.0i da Empresa "F".
\end{abstract}

Termos para indexação: Glycine max (L.) Merrill, vigor, colheita, beneficiamento, comercialização.

\section{Introduction}

The soybean production in the state of Santa Catarina is important on a national scale, primarily due to favorable climatic conditions. In the state, there are cooperatives and companies that produce high quality seeds, designed to meet the needs of the domestic and foreign markets, with exports to Paraguay, Uruguay and Argentina. The market demand,

${ }^{1}$ Submitted on $05 / 25 / 2015$. Accepted for publication on $08 / 11 / 2015$.

${ }^{2}$ Companhia Integrada de Desenvolvimento Agrícola de Santa Catarina, Secretaria de Estado da Agricultura e da Pesca, 89820-000 - Xanxerê, SC, Brasil. ${ }^{3}$ Departamento de Fitotecnia, UFPel, Caixa Postal 354, 96010-900 - Capão do Leão, RS, Brasil. the industry's professionalism and good climatic conditions guarantee significant participation in the Brazilian scene. This makes Santa Catarina among the largest producers in the soybean seed business, with about 86.000 tons during the 2013/14 harvest (CONAB, 2014).

The use of high quality seeds is the basis for agriculture production, is related to the ability of the seed perform its vital functions, and that the effects on quality are generally

${ }^{4}$ Sementes Seriema/Jotabasso, Caixa Postal 123, 78705-600 - Rondonópolis, MT, Brasil.

*Corresponding author <cristiane.deuner@hotmail.com> 
translated by the decrease in the percentage of germination, increase of abnormal seedlings and reduced seedling vigor (Toledo et al., 2009; Kappes et al., 2012). According Kolchinski et al. (2006) high vigor seeds originated plants with larger leaf area index, higher dry matter production and higher productivity of seeds in relation to the use of low vigor. The physiological seed quality may be affected by genetic factors, adversity during seed development after ripening and physiological processes that occur before and after harvest (Braccini et al., 2001).

Even under ideal storage conditions, seed quality cannot be improved or maintained. Thus, the rate of degenerative changes depends on the conditions under which the seed is exposed in the field before and during harvesting, as well as the harvesting method, and drying, processing and storage conditions (Ávila and Albrecht, 2010).

High temperatures and humidity are the main causes of the reduction of seed germination and the higher the time of exposure to these conditions greater damage to seeds (Binotti et al., 2008). In addition to moisture, one of the main problems causing a reduction in soybean seed quality is a high level of mechanical damage, which are practically inevitable as they may occur in several steps mechanized and be aggravated every day, given the growing demand for mechanization of the agricultural sector, which keeps the mechanical damage as one of the most serious problems in seed technology (Pinto et al., 2012). The soybean seed embryo is protected by a relatively fragile integument, the embryo is shallow and susceptible to mechanical injuries caused by other external agents demonstrating that the seed can suffer mechanical damage during processing stages (Marcos - Filho, 2013).

The state of Santa Catarina is recognized for producing high quality soybean seeds, thanks to the use by producers, cooperatives and business of modern technologies associated with favorable climatic conditions in the seeds of soybean producing areas evaluated in this study. The rains are well-distributed, mild night temperatures during the growing season, culminating with low temperatures and low oscillation relative humidity during storage. Undoubtedly, there is potential for significant growth, but it is first necessary to identify which areas/regions present ideal climate, topographical and technological conditions for this growth. Thus, the objective of this study was to evaluate the physiological quality of soybean seeds produced by companies in different regions of the state of Santa Catarina.

\section{Material and Methods}

This work was conducted in the state of Santa Catarina, in the main areas for the production of commercial soybean seed. Therefore, the study proceeded the analysis of seeds coming from cooperatives in the regions of Xanxerê (companies A, B and C), Abelardo Luz (companies D and E), Campos Novos (F and $\mathrm{G}$ companies) and Canoinhas (only one producer has been reported-Company $\mathrm{H}$ ). In each company, approximately $2 \mathrm{~kg}$ of seed samples were collected from three cultivars on three dates: upon reception at the seed processing unit, at the end of processing and before marketing. The cultivars of each company are presented in Table 1 .

Table 1. Soybean cultivars, locations and seed companies that participated in this study.

\begin{tabular}{ccc}
\hline REGION & COMPANY & CULTIVAR / LOTS \\
\hline \multirow{2}{*}{ Xanxerê } & A & NA 5909 RR, CD 236 RR, NA 4990 RG \\
& B & CD 221, Don Mario 7.0i, CD 202 \\
& C & NS 4823, CD 202, NK 412113 \\
\hline \multirow{2}{*}{ Abelardo Luz } & D & Don Mario 5.8i, NA 4990 RG, BMX Potência RR \\
& E & A.6411 RG, BMX Titan RR, NA 4990 RG \\
\hline \multirow{2}{*}{ Campos Novos } & F & BRS 294, Don Mario 7.0i, BRS 295 \\
& G & Don Mario 5.8i, BMX Energia RR, NS 4823 RG \\
\hline Canoinhas & H & NK 7059 RR, SYN 3358 RR, SYN 1049 RR
\end{tabular}

The size of the sample was due to the weight of the lot in accordance with the Brazilian Rules for Seed Testing (RAS) (Brasil, 2009). In each evaluation, the single samples were homogenized to form the composite sample of each cultivar and date, which were packed in kraft paper bags with a $2 \mathrm{~kg}$ capacity and forwarded to the HSN Seed Analysis Laboratory Ltd. (Quality) Abelardo Luz/SC, where they remained stored under a cool, dry environment $\left(15^{\circ} \mathrm{C} / 40 \% \mathrm{RH}\right)$ to perform the analysis. The samples were then evaluated for their physiological quality via the germination test, as well as the accelerated aging and seedling length measurements, all within the studied periods (reception, after processing and before marketing).

Germination: this step was conducted using 200 seeds, in four replicates of 50 seeds for each repetition, placed in germitest paper previously moistened with distilled water 
equivalent to 2.5 times the mass of the dry paper. The germination was set to maintain a constant temperature of $25{ }^{\circ} \mathrm{C}$. The evaluations were performed at five days (first count) and eight days (final score), reflecting the percentage of normal seedlings, according to the criteria established by analysis for RAS (Brasil, 2009).

Accelerated aging: it was conducted with four replicates of 50 seeds arranged on aluminum screen placed in plastic boxes of the gerbox type, containing $40 \mathrm{~mL}$ of water, according to the methodology described by (Krzyzanowski et al., 1991). Thereafter, the boxes were taken of the BOD to a growth chamber regulated to maintain constant temperature at $41^{\circ} \mathrm{C}$ for 48 hours. After this period, the seeds were submitted to germination test described above and the evaluation was performed on the fifth day after sowing, computing the normal seedlings.

Seedling length: the seedling length was measured using Nakagawa's (1999) procedures. Ten replicates of 10 soybean seeds were used for each treatment. A line was drawn in the upper third of germitest role in the longitudinal direction. The sheets were pre-moistened with distilled water equal to 2.5 times the dry weight of the paper and then seedling was performed so that the heel stayed facing the bottom of the paper. The rolls were stored in plastic bags that were vertically positioned in the germination chamber for five days at $25{ }^{\circ} \mathrm{C}$. After this period, the normal seedlings were measured (primary root and hypocotyl) using a graduated scale in millimeters. The results of the seedling length were expressed in $\mathrm{cm}$, and the average of the total normal seedlings was obtained for each replicate.

For each site and company, an experiment was conducted with two factors: cultivars (three cultivars per company, varying among the companies studied) and the time of evaluation (reception at the SPU, end of the processing and marketing), arranged in a completely randomized design.

After the tests, the data, expressed as percentages, were transformed by $\operatorname{arcsen} \sqrt{x} / 100$, with the original data expressed. The data were submitted to an analysis of variance and were then compared with each other using a Duncan test at the level of 5\% probability. The software Winstat 1.0 (Machado and Conceição, 2003) was used for this analysis.

\section{Results and Discussion}

\section{Xanxerê Region}

Analyzing the results of the germination test, there were no significant differences in seed germination between the times tested in the Xanxerê region companies "A" and "C" (Table 2) and among cultivars in companies "A" and "B" (Table 2). The cultivars CD 221 and CD 202 from company "B" had lower germination in marketing, significantly differing from the other evaluated times, though remaining within the minimum standards required for marketing soybeans, which is $80 \%$ (Brasil, 2005). According to Carvalho et al. (2014) in the post-harvest period, seeds require storage under appropriate conditions and packaging, to maintain the quality until the moment of sowing.

The force was analyzed using the accelerated aging test (Table 2), and significant differences were found between the ages evaluated for all cultivars and companies, except for cultivars NA 4990 RG from company "A". It may be noted that the seeds of the cultivars NA 5909 RR and CD 236 showed less force at reception, which can be explained by the fact that these seeds have not yet been benefited. It is possible to improve the quality of a seed lot through the removal of damaged seeds and crop residues that impair their quality. According to Silva et al. (2011) the processing aims to improve the physical characteristics of a seed lot, as the maximum quality is a direct result of the production conditions in the field. Assessing the processing of contributions as maize seed, Ferreira and Sá (2010), observed that the processing promoted improvement in the quality of seeds, and that obtained after the gravity table and ready for bagging performed better. However, Santos et al. (2013) concluded that the processing did not improve the physiological and sanitary quality of peanut seeds.

The seeds from the company "C" (Table 2) showed a reduction in force for all cultivars, comparing the results of the reception time with marketing, which suggests that this seed lot has gotten a cleaner receipt or seeds have deteriorated during the following steps. The process of deterioration is inevitable and occurs after physiological maturity and whose final result is the most drastic loss of viability (Marcos- Filho, 2005).

Comparing the results of the force through the seedling length test, there is no significant difference between the time measured in most cultivars. The lowest value was on receipt in cultivar CD 202 from company "B". In the results presented in Table 2, it can be observed that all cultivars showed high percentages of germination and vigor during the evaluation period, even with significant differences between the results for the accelerated aging and seedling length.

Journal of Seed Science, v.37, n.3, p.226-233, 2015 
Table 2. Physiological quality of lots of soybean seeds obtained in three stages of the production process, the three companies, the region of Xanxerê/SC, called A, B and C. 2014.

\begin{tabular}{|c|c|c|c|c|c|c|c|c|c|c|c|c|c|}
\hline \multirow[b]{2}{*}{ Test } & \multirow[b]{2}{*}{ Time } & \multicolumn{4}{|c|}{ Company "A" } & \multicolumn{4}{|c|}{ Company "B" } & \multicolumn{4}{|c|}{ Company "C" } \\
\hline & & $\begin{array}{c}\text { NA } \\
5909 \\
\text { RR }\end{array}$ & $\begin{array}{c}\text { CD } 236 \\
\text { RR }\end{array}$ & $\begin{array}{c}\text { NA } \\
4990 \\
\text { RG }\end{array}$ & Avg. & CD 221 & $\begin{array}{c}\text { Don Mario } \\
7.0 \mathrm{i}\end{array}$ & CD 202 & Avg. & $\begin{array}{c}\text { NS } \\
4823\end{array}$ & CD 202 & $\begin{array}{c}\text { NK } \\
412113\end{array}$ & Avg. \\
\hline \multirow{3}{*}{$\begin{array}{l}\mathrm{G} \\
(\%)\end{array}$} & Recep. & $89 \mathrm{Aa}$ & $90 \mathrm{Aa}$ & $90 \mathrm{Aa}$ & 90 & $90 \mathrm{Aa}$ & $91 \mathrm{Aa}$ & $89 \mathrm{Aa}$ & 90 & $85 \mathrm{Ab}$ & $92 \mathrm{Aa}$ & $91 \mathrm{Aa}$ & 89 \\
\hline & AP & $91 \mathrm{Aa}$ & $92 \mathrm{Aa}$ & $91 \mathrm{Aa}$ & 91 & $93 \mathrm{Aa}$ & $92 \mathrm{Aa}$ & $90 \mathrm{Aa}$ & 92 & $84 \mathrm{Ab}$ & $87 \mathrm{Aa}$ & $87 \mathrm{Aa}$ & 86 \\
\hline & $\mathrm{BM}$ & $89 \mathrm{Aa}$ & $90 \mathrm{Aa}$ & $89 \mathrm{Aa}$ & 89 & $85 \mathrm{Ba}$ & $88 \mathrm{Aa}$ & $86 \mathrm{Ba}$ & 86 & $85 \mathrm{Ab}$ & $89 \mathrm{Aa}$ & $88 \mathrm{Aa}$ & 87 \\
\hline \multicolumn{2}{|c|}{ Average } & 90 & 91 & 90 & & 89 & 90 & 88 & & 85 & 89 & 89 & \\
\hline \multicolumn{2}{|c|}{$\mathrm{CV}(\%)$} & & 3.57 & & & & 2.74 & & & & 4.50 & & \\
\hline \multirow{3}{*}{$\begin{array}{l}\text { AA } \\
(\%)\end{array}$} & Recep. & $86 \mathrm{Bb}$ & $85 \mathrm{Bb}$ & $90 \mathrm{Aa}$ & 87 & $87 \mathrm{Aab}$ & $89 \mathrm{Aa}$ & $86 \mathrm{Ab}$ & 87 & $80 \mathrm{Ab}$ & $88 \mathrm{Aa}$ & $87 \mathrm{Aa}$ & 85 \\
\hline & AP & $91 \mathrm{Aa}$ & $91 \mathrm{Aa}$ & 90 Aa & 91 & $90 \mathrm{Aa}$ & $91 \mathrm{Aa}$ & $89 \mathrm{Aa}$ & 90 & $80 \mathrm{Ab}$ & $85 \mathrm{Aba}$ & $84 \mathrm{ABa}$ & 83 \\
\hline & $\mathrm{BM}$ & $88 \mathrm{ABa}$ & $88 \mathrm{ABa}$ & $88 \mathrm{Aa}$ & 88 & $77 \mathrm{Bc}$ & $85 \mathrm{Ba}$ & $81 \mathrm{Bb}$ & 81 & $78 \mathrm{Ba}$ & $78 \mathrm{Ba}$ & $82 \mathrm{Ba}$ & 79 \\
\hline \multicolumn{2}{|c|}{ Average } & 88 & 88 & 89 & & 85 & 88 & 85 & & 79 & 84 & 84 & \\
\hline \multicolumn{2}{|c|}{$\mathrm{CV}(\%)$} & & 1.28 & & & & 1.93 & & & & 6.03 & & \\
\hline \multirow{3}{*}{$\begin{array}{l}\mathrm{SL} \\
(\mathrm{cm})\end{array}$} & Recep. & $19.2 \mathrm{Ab}$ & $20.6 \mathrm{Aa}$ & $20.3 \mathrm{Ab}$ & 20.1 & 19.1 Aab & $19.4 \mathrm{Aa}$ & $16.8 \mathrm{Ab}$ & 18.4 & $21.2 \mathrm{Aa}$ & $21.6 \mathrm{Aa}$ & $18.9 \mathrm{Aa}$ & 20.5 \\
\hline & AP & $20.6 \mathrm{Aa}$ & $20.9 \mathrm{Aa}$ & $19.9 \mathrm{Aa}$ & 20.5 & $17.7 \mathrm{ABa}$ & $18.7 \mathrm{Aa}$ & $17.8 \mathrm{Aa}$ & 18.1 & $20.4 \mathrm{Aa}$ & $21.7 \mathrm{Aa}$ & $20.0 \mathrm{Aa}$ & 20.7 \\
\hline & $\mathrm{BM}$ & $21.7 \mathrm{Aa}$ & $21.4 \mathrm{Aa}$ & $18.8 \mathrm{Bb}$ & 20.6 & $17.3 \mathrm{Ba}$ & $19.2 \mathrm{Aa}$ & $17.3 \mathrm{Aa}$ & 17.9 & $20.5 \mathrm{Aa}$ & $21.0 \mathrm{Aa}$ & $18.9 \mathrm{Aa}$ & 20.2 \\
\hline \multicolumn{2}{|c|}{ Average } & 20.5 & 21.0 & 19.7 & & 18.0 & 19.1 & 17.3 & & 20.7 & 21.4 & 19.3 & \\
\hline \multicolumn{2}{|c|}{ CV $(\%)$} & & 3.58 & & & & 7.99 & & & & 8.86 & & \\
\hline
\end{tabular}

Data followed by the same letter, uppercase column for each response variable and lower in line at each company, do not differ at the $\mathrm{p}<0.05$ level according to Duncan test. G: germination; AA: accelerated aging; SL: seedling length; Recep.: reception; AP: after processing; BM: before marketing. Avg.: average.

\section{Abelardo Luz Region}

The evaluation result of the germination test for the region of Abelardo Luz shows that soybeans produced by company "D" (Table 3) maintained the germination percentage between the periods evaluated. Among the cultivars analyzed, there was a significant difference in the BMX Potência RR cultivar, which showed lower germination at reception and before marketing. Nevertheless, the cultivars showed a high germination percentage, which was within the minimum standards required for marketing soybeans (Brasil, 2005).

Company "E" (Table 3) showed similar results as above, with a significant difference only for treatment time for the NA 4990 RG cultivar, reducing the germination percentage after processing and before marketing by six and 11 percentage points, respectively, compared to reception. These low germination percentages may be associated with damage during processing and the deterioration of the seeds during the storage period, enhanced by the interaction with some fungi and insects, accelerating seed metabolism and reducing the germination and vigor. Queiroz et al. (2012) evaluated the simulation of mechanical damages in common bean during the improvement process, found that bean seed germination decreases in proportion to the number of steps of the beneficiation process increased and mechanical damage of bean seeds were cumulative and increased the proportion that increased the passages of seeds by simulation machine of the beneficiation process of the seeds. Kirchner et al. (2014) also found that the mechanical damage during processing reduce the quality of soybean seeds.

Analyzing the results of accelerated aging for the Company "D" (Table 3), it is observed that the cultivar NA 4990 RG showed less effect on reception when compared to other cultivars. Later there was an increase in the force of the lot, which may be related to efficiency improvement, which enabled the elimination of seeds with low vigor, improving the physiological quality of the seed lot. Similar results were obtained by Fessel et al. (2003), which concluded that the corn seeds can enhance the quality of a lot in terms of germination, vigor and health. Pereira et al. (2012) benefiting from rice seeds, observed that with the pre-cleaning machines, air and sieves and gravity table, there was an increase of the physiological potential of the lot and the physical quality throughout the processing. In bean-kid seeds, Mertz et al. (2007) found an increase in physiological quality after submitting the seeds to the table of gravity.

The results of the seeds from company "E" (Table 3) indicate that there are significant differences in vigor evaluated by the accelerated aging test, among cultivars and the studied periods. These differences are more pronounced in NA 4990 $\mathrm{RG}$, where there was a loss of force during the storage period. According to Cunha et al. (2009) the deterioration can be intensified with longer storage period even refrigerated, damaging the force of stored seeds. 
Table 3. Physiological quality of lots of soybean seeds obtained in three stages of the production process, the two companies, the region of Abelardo Luz/SC, called D and E. 2014.

\begin{tabular}{|c|c|c|c|c|c|c|c|c|c|}
\hline \multirow[b]{2}{*}{ Test } & \multirow[b]{2}{*}{ Time } & \multicolumn{4}{|c|}{ Company "D" } & \multicolumn{4}{|c|}{ Company "E" } \\
\hline & & $\begin{array}{c}\text { Don } \\
\text { Mario } \\
5.8 \mathrm{i}\end{array}$ & $\begin{array}{c}\text { NA } \\
4990 \\
\text { RG } \\
\end{array}$ & $\begin{array}{c}\text { BMX } \\
\text { Potência } \\
\text { RR }\end{array}$ & Average & $\begin{array}{c}\text { A. } 6411 \\
\text { RG }\end{array}$ & $\begin{array}{c}\text { BMX Titan } \\
\text { RR }\end{array}$ & $\begin{array}{c}\text { NA } 4990 \\
\text { RG }\end{array}$ & Average \\
\hline \multirow{3}{*}{$\mathrm{G}(\%)$} & Recep. & $92 \mathrm{Aa}$ & $86 \mathrm{Aa}$ & $85 \mathrm{Ab}$ & 88 & $89 \mathrm{Aa}$ & $91 \mathrm{Aa}$ & $91 \mathrm{Aa}$ & 90 \\
\hline & $\mathrm{AP}$ & $90 \mathrm{Aa}$ & $90 \mathrm{Aa}$ & $85 \mathrm{Aa}$ & 88 & $92 \mathrm{Aa}$ & $93 \mathrm{Aa}$ & $85 \mathrm{Bb}$ & 90 \\
\hline & $\mathrm{BM}$ & $89 \mathrm{Aa}$ & $90 \mathrm{Aa}$ & $84 \mathrm{Ab}$ & 88 & $90 \mathrm{Aa}$ & $91 \mathrm{Aa}$ & $80 \mathrm{Cb}$ & 87 \\
\hline \multicolumn{2}{|c|}{ Average } & 90 & 89 & 85 & & 90 & 92 & 85 & \\
\hline \multicolumn{2}{|c|}{$\mathrm{CV}(\%)$} & & 2.72 & & & & 2.72 & & \\
\hline \multirow{3}{*}{$\begin{array}{l}\text { AA } \\
(\%)\end{array}$} & Recep. & $92 \mathrm{Aa}$ & $77 \mathrm{Bc}$ & $83 \mathrm{Ab}$ & 84 & $82 \mathrm{Bb}$ & $90 \mathrm{Aa}$ & $89 \mathrm{Aa}$ & 87 \\
\hline & $\mathrm{AP}$ & $87 \mathrm{Aa}$ & $88 \mathrm{Aa}$ & $80 \mathrm{Ab}$ & 85 & $92 \mathrm{Aa}$ & $91 \mathrm{Aa}$ & $75 \mathrm{Bc}$ & 86 \\
\hline & $\mathrm{BM}$ & $81 \mathrm{Bb}$ & $87 \mathrm{Aa}$ & $80 \mathrm{Ab}$ & 83 & $82 \mathrm{Ba}$ & $85 \mathrm{Ba}$ & $68 \mathrm{Cc}$ & 78 \\
\hline \multicolumn{2}{|c|}{ Average } & 87 & 84 & 81 & & 85 & 89 & 77 & \\
\hline \multicolumn{2}{|c|}{$\mathrm{CV}(\%)$} & & 2.02 & & & & 2.01 & & \\
\hline \multirow{3}{*}{$\begin{array}{l}\mathrm{SL} \\
(\mathrm{cm})\end{array}$} & Recep. & $15.9 \mathrm{a}$ & $16.3 \mathrm{Aa}$ & $17.5 \mathrm{Aa}$ & 16.6 & $18.0 \mathrm{Ab}$ & $21.3 \mathrm{Aa}$ & $16.6 \mathrm{Ab}$ & 18.6 \\
\hline & $\mathrm{AP}$ & $16.6 \mathrm{a}$ & $16.3 \mathrm{Aa}$ & $17.9 \mathrm{Aa}$ & 16.9 & $18.7 \mathrm{Aa}$ & $20.6 \mathrm{Aa}$ & $16.4 \mathrm{Ab}$ & 18.6 \\
\hline & $\mathrm{BM}$ & $17.6 \mathrm{a}$ & $17.7 \mathrm{Aa}$ & $16.9 \mathrm{Aa}$ & 17.4 & $19.8 \mathrm{Aa}$ & $21.6 \mathrm{Aa}$ & $16.2 \mathrm{Ab}$ & 19.2 \\
\hline \multicolumn{2}{|c|}{ Average } & 16.7 & 16.8 & 17.5 & & 18.8 & 21.2 & 16.4 & \\
\hline \multicolumn{2}{|c|}{$\mathrm{CV}(\%)$} & & 7.76 & & & & 7.76 & & \\
\hline
\end{tabular}

Data followed by the same letter, uppercase column for each response variable and lower in line at each company, do not differ at the $p<0.05$ level according to Duncan test. G: germination; AA: accelerated aging; SL: seedling length; Recep.: reception; AP: after processing; BM: before marketing.

As for the strength test and seedling length (Table 3), the seeds from both companies failed to demonstrate significant differences between the periods evaluated, but when evaluated the treatment cultivate, there was a significant difference between the NA 4990 RG cultivar after processing and before marketing, and the A.6411 RG cultivar on the reception. Please note that for Marcos - Filho (2005), the force is comprised of a set of characteristics that determine the physiological potential of seeds. Environmental conditions and management during pre- and post-harvest influence the force.

\section{Campos Novos Region}

The results of the germination tests in the Campos Novos region show that the soybean seeds of BRS 295 Company "F" (Table 4) showed a decrease in the percentage of germination nine and eight percentage points in the processing steps and marketing, respectively. The seeds of this variety, as well as the Don Mario 7.0i, reached germination less than the minimum standards required for marketing soybeans. These low germination percentages may be associated with problems during collection, or because of issues with the total rainfall during ripening and harvesting, which caused a loss of strength and the deterioration of seeds. As MarcosFilho (2005) stated, if weather conditions are favorable from the point of physiological maturity until harvest time, decay problems are mitigated, however, if the delay of harvest from the physiological maturity does not have a negative influence on the quality of seed, due to its exposure to unfavorable environmental conditions. Early harvest reduces the risks in the field and allows for obtaining better quality seeds, which are harvested closer to maturity (Terasawa et al., 2009).

The information of the company from germination test "G" in the Campos Novos region (Table 4) demonstrates a high percentage of germination even with a loss in germination for the BMX Energia RR and NS 4823 RG cultivars between reception and pre-commercialization. However, this does not necessarily meet the minimum standards required for marketing in any of the cultivars analyzed.

The result of the accelerated aging test for company "F" (Table 4) allows us to identify significant differences in treatment time between BRS 295 and BRS 294, the first of which presents low vigor after processing and prior to marketing, which can be attributed to damage sustained in the processing step. These mechanical injuries caused by processing occur by contact of the seeds with hard surfaces, causing breaks, cracks and abrasions, causing reduction in germination and vigor (Krzyzanowski et al., 1999), and hinder the improvement of operations. However, BRS 294 presents low vigor at time of reception, which can be linked to contaminants in seeds, because damaged seeds, deformed seeds and seeds from other species can diminish the overall quality. 
Table 4. Physiological quality of lots of soybean seeds obtained in three stages of the production process, the two companies, the region of Campos Novos/SC, called F and G. 2014.

\begin{tabular}{|c|c|c|c|c|c|c|c|c|c|}
\hline \multirow[b]{2}{*}{ Test } & \multirow[b]{2}{*}{ Time } & \multicolumn{4}{|c|}{ Company "F" } & \multicolumn{4}{|c|}{ Company "G” } \\
\hline & & BRS 295 & BRS 294 & $\begin{array}{c}\text { Don Mario } \\
7.0 \mathrm{i}\end{array}$ & Average & Don Mario 5.8i & BMX Energia & NS 4823 & Average \\
\hline \multirow{3}{*}{$\mathrm{G}(\%)$} & Recep. & $80 \mathrm{Aa}$ & $80 \mathrm{Ba}$ & $79 \mathrm{Aa}$ & 80 & $90 \mathrm{Aa}$ & $92 \mathrm{Aa}$ & $92 \mathrm{Aa}$ & 91 \\
\hline & $\mathrm{AP}$ & $71 \mathrm{Bc}$ & $85 \mathrm{Aa}$ & $81 \mathrm{Aa}$ & 79 & $89 \mathrm{Aa}$ & $91 \mathrm{Aa}$ & $90 \mathrm{Aa}$ & 90 \\
\hline & $\mathrm{BM}$ & $72 \mathrm{Bc}$ & $86 \mathrm{Aa}$ & $79 \mathrm{Ab}$ & 82 & 89 Аа & $86 \mathrm{Bb}$ & $82 \mathrm{Bc}$ & 86 \\
\hline \multicolumn{2}{|c|}{ Average } & 74 & 84 & 80 & & 89 & 90 & 88 & \\
\hline \multicolumn{2}{|c|}{$\mathrm{CV}(\%)$} & \multicolumn{3}{|c|}{2.56} & \multicolumn{5}{|c|}{2.17} \\
\hline \multirow{3}{*}{$\begin{array}{l}\text { AA } \\
(\%)\end{array}$} & Recep. & $78 \mathrm{Aa}$ & $79 \mathrm{Ba}$ & $76 \mathrm{Ab}$ & 78 & $89 \mathrm{Aa}$ & $91 \mathrm{Aa}$ & $91 \mathrm{Aa}$ & 90 \\
\hline & $\mathrm{AP}$ & $65 \mathrm{Bc}$ & $83 \mathrm{Aa}$ & $78 \mathrm{Ab}$ & 75 & $86 \mathrm{Aa}$ & $88 \mathrm{Ba}$ & $88 \mathrm{Ba}$ & 87 \\
\hline & $\mathrm{BM}$ & $65 \mathrm{Bc}$ & $82 \mathrm{Aa}$ & $76 \mathrm{Ab}$ & 74 & $87 \mathrm{Aa}$ & $82 \mathrm{Cb}$ & $77 \mathrm{Cc}$ & 82 \\
\hline \multicolumn{2}{|c|}{ Average } & 69 & 81 & 77 & & 87 & 87 & 85 & \\
\hline \multicolumn{2}{|c|}{ CV $(\%)$} & \multicolumn{3}{|c|}{2.1} & \multicolumn{5}{|c|}{2.26} \\
\hline \multirow{3}{*}{$\begin{array}{l}\mathrm{SL} \\
(\mathrm{cm})\end{array}$} & Recep. & 20.0 Aa & $19.5 \mathrm{ABa}$ & 20.9 Аа & 20.5 & $19.8 \mathrm{Aa}$ & $18.8 \mathrm{Aa}$ & 19.7 Аa & 19.4 \\
\hline & AP & $21.3 \mathrm{Aa}$ & $18.5 \mathrm{Ba}$ & $21.3 \mathrm{Aa}$ & 20.4 & $20.2 \mathrm{Aa}$ & $19.2 \mathrm{Aa}$ & 19.7 Aa & 19.7 \\
\hline & $\mathrm{BM}$ & $18.5 \mathrm{Ba}$ & $20.1 \mathrm{Aa}$ & $21.1 \mathrm{Aa}$ & 20.0 & $20.1 \mathrm{Aa}$ & $19.5 \mathrm{Aa}$ & $20.4 \mathrm{Aa}$ & 20.0 \\
\hline \multicolumn{2}{|c|}{ Average } & 20.2 & 19.4 & 21.1 & & 20.0 & 19.1 & 19.9 & \\
\hline \multicolumn{2}{|c|}{$\mathrm{CV}(\%)$} & \multicolumn{3}{|c|}{3.53} & \multicolumn{5}{|c|}{3.04} \\
\hline
\end{tabular}

Data followed by the same letter, uppercase column for each response variable and lower in line at each company, do not differ at the $\mathrm{p}<0.05$ level according to Duncan test. G: germination; AA: accelerated aging; SL: seedling length; Recep.: reception; AP: after processing; BM: before marketing.

Company "G" (Table 4) showed significant differences in the accelerated aging test between sampling seasons in BMX Energia RR and NS 4823 RG cultivars, being worse before marketing. According to Silva et al. (2010), the accelerated aging is used in quality control programs in the seed companies, for a few days can have an idea of the storage potential of processed lots, and the possible performance of these at high temperature conditions after sowing.

To force the seedling length test, significant differences between the cultivars studied have not been identified. However, the BRS 294 and BRS 295 from company "F" (Table 4) showed differences between the periods evaluated.

\section{Canoinhas Region}

The results of the germination test on the soybean seeds produced in the region of Canoinhas at company " $\mathrm{H}$ " (Table 5) show that there was maintenance of germination in all cultivars, with no significant differences between the periods evaluated. However, there were differences among cultivars, being significant at the points of reception and marketing for SYN 3358 RR, which showed lower germination.

The result of the accelerated aging test in Canoinhas region's company " $\mathrm{H}$ " (Table 5) showed no significant difference in the analyzed periods, showing that the seeds maintained physiological quality during these steps. According to Tunes et al. (2010), the initial seed quality is a determining factor, among others, of their storage capacity.
But, the length of seedlings revealed significant differences for both variables, except between seasons for SYN 1049 RR. This is very important because the quality of seeds reflects the development of culture forming more vigorous plants, uniformity of population and absence of diseases transmitted by seed (Silva et al., 2010) factors that influence the grain yield (Scheeren et al., 2010).

The results of force for the cultivars of company " $\mathrm{H}$ " indicate that the seeds have high physiological quality in all cultivars analyzed (Table 5). These results are possibly associated with the production system employed by the producer. All seed production fields are driven by only a licensed producer, using appropriate technologies at different stages of the production process, extending during the stages of harvest, using harvesters well adjusted with axial system, processing with modern machines and adequate regulation and monitoring the seeds during storage. Another advantage is that being an individual producer, there is not a mixture of seeds from other producers in UBS, ensuring the maintenance of seed quality during the whole process, from harvesting to marketing.

In the other companies studied, there are several producers, rather than just one, since the cultivars come from cooperatives. In the same manner as the single producer, the entire process from harvest to commercialization is controlled in order to avoid varietal mixtures, maintaining the quality of seeds. However, producers are reputable and cooperative people in the company. In general, the regions have favorable conditions 
for producing soybean seeds of a high physiological quality, but it is necessary for companies to identify the causes of some cultivars having low quality or germination percentages below the recommended standards for marketing.

Tabela 5. Physiological quality of lots of soybean seeds obtained in three stages of the production process, of a company, the region of Canoinhas/SC, called H. 2014.

\begin{tabular}{|c|c|c|c|c|c|}
\hline \multirow{2}{*}{ Test } & \multirow{2}{*}{ Time } & \multicolumn{4}{|c|}{ Company "H" } \\
\hline & & NK 7059RR & SYN 3358 RR & SYN 1049 RR & Average \\
\hline \multirow{3}{*}{ G (\%) } & $\mathrm{R}$ & $95 \mathrm{Aa}$ & $89 \mathrm{Ab}$ & $91 \mathrm{Aa}$ & 92 \\
\hline & $\mathrm{AP}$ & $91 \mathrm{Aa}$ & $88 \mathrm{Aa}$ & $90 \mathrm{Aa}$ & 90 \\
\hline & $\mathrm{BM}$ & $92 \mathrm{Aa}$ & $86 \mathrm{Ab}$ & $93 \mathrm{Aa}$ & 90 \\
\hline Average & & 93 & 88 & 91 & \\
\hline CV $(\%)$ & & & 1.81 & & \\
\hline \multirow{3}{*}{ AA (\%) } & $\mathrm{R}$ & $92 \mathrm{Aa}$ & $89 \mathrm{Aa}$ & $91 \mathrm{Aa}$ & 91 \\
\hline & $\mathrm{AP}$ & $91 \mathrm{Aa}$ & $88 \mathrm{Aa}$ & $90 \mathrm{Aa}$ & 90 \\
\hline & $\mathrm{BM}$ & $92 \mathrm{Aa}$ & $86 \mathrm{Ab}$ & $93 \mathrm{Aa}$ & 90 \\
\hline Average & & 92 & 88 & 91 & \\
\hline CV (\%) & & & 1.76 & & \\
\hline \multirow{3}{*}{$\mathrm{SL}(\mathrm{cm})$} & $\mathrm{R}$ & $20.9 \mathrm{Bb}$ & $20.7 \mathrm{Bb}$ & $22.4 \mathrm{Aa}$ & 21.4 \\
\hline & $\mathrm{AP}$ & $22.9 \mathrm{Aa}$ & $21.2 \mathrm{ABb}$ & $21.5 \mathrm{Ab}$ & 21.9 \\
\hline & $\mathrm{BM}$ & $22.5 \mathrm{Aa}$ & $22.3 \mathrm{Aa}$ & $22.3 \mathrm{Aa}$ & 22.3 \\
\hline Average & & 22.1 & 21.4 & 22.1 & \\
\hline CV (\%) & & & 3.63 & & \\
\hline
\end{tabular}

Data followed by the same letter, uppercase column for each response variable and lower in line at each company, do not differ at the $\mathrm{p}<0.05$ level according to Duncan test. G: germination; AA: accelerated aging; SL: seedling length; R.: reception; AP: after processing; BM: before marketing.

\section{Conclusions}

Soybeans seeds produced in the state of Santa Catarina have adequate quality for sowing and have germination within the standards required for marketing, except for the BRS 295 and Don Mario 7.0i cultivars from company "F", Campos Novos region.

\section{References}

ÁVILA, M.R.; ALBRECHT, L.P. Isoflavonas e a qualidade das sementes de soja. Informativo Abrates, v.20, p.15-29, 2010. http://www.abrates.org.br/ images/stories/informativos/v20n12/artigo02.pdf

BINOTTI, F.F.S.; HAGA, K.I.; CARDOSO, E.D.; ALVES, C.Z.; SÁ, M.E.; ARF, O. Efeito do período de envelhecimento acelerado no teste de condutividade elétrica e na qualidade fisiológica de sementes de feijão. Acta Scientiarum Agronomy, v.30, n.2, p.247-254, 2008. http://periodicos.uem.br/ ojs/index.php/ActaSciAgron/article/view/1736

BRACCINI, A.L.; BRACCINI, M.C.L.; SCAPIM, C.A. Mecanismos de deterioração de sementes: Aspectos bioquímicos e fisiológicos. Informativo Abrates, v.11, n.1, p.10-15, 2001.

BRASIL. Padrões para produção e comercialização de sementes de soja, 2005. $<$ http://www.agricultura.pr.gov.br/arquivos/File/PDF/padroes_soja.pdf $>$. Accessed on: Dec. $06^{\text {th }} 2014$.
BRASIL. Ministério da Agricultura, Pecuária e Abastecimento. Regras para análise de sementes. Ministério da Agricultura, Pecuária e Abastecimento. Secretaria de Defesa Agropecuária. Brasília: MAPA-ACS, 2009. 395p. http:// www.agricultura.gov.br/arq_editor/file/2946_regras_analise_sementes.pdf

CARVALHO, E.R.R.; MAVAIEIE, D.P. R.; OLIVEIRA, J.A.; CARVALHO, M.V.; VIEIRA, A.R. Alterações isoenzimáticas em sementes de cultivares de soja em diferentes condições de armazenamento. Pesquisa Agropecuária Brasileira, v.49, n.12, p.967-976, 2014. http://www.scielo.br/pdf/pab/ v49n12/0100-204X-pab-49-12-00967.pdf

CONAB. Acompanhamento da safra brasileira de grãos. V.2 - SAFRA 2014/15 N.3 - Terceiro Levantamento Dezembro/2014, 2014. http://www. conab.gov.br/OlalaCMS/uploads/arquivos/13 $12 \quad 10 \quad 16 \quad 06 \quad 56$ boletim portugues_dezembro_2013.pdf Accessed on: Dec $06^{\text {th }} .2014$.

CUNHA, J.P.A.R.; OLIVEIRA, P.; SANTOS, C.M.; MION, R.L. Qualidade das sementes de soja após a colheita com dois tipos de colhedora e dois períodos de armazenamento. Ciência Rural, v.39, p.1420-1425, 2009. http:// www.scielo.br/scielo.php?script $=$ sci_nlinks\&ref $=000107 \&$ pid $=$ S1415$4366201400080001000006 \& \operatorname{lng}=$ en

FERREIRA, R.L.; SÁ, M.E. Contribuição de etapas do beneficiamento na qualidade fisiológica de sementes de dois híbridos de milho. Revista Brasileira de Sementes, v.32, n.4, p.99 - 110, 2010. http://www.scielo.br/pdf/ rbs/v32n4/11.pdf

FESSEL, F.A.; SADER, R.; PAULA, R.C.; GALLI, J.A. Avaliação da qualidade física, fisiológica e sanitária de sementes de milho durante o beneficiamento. Revista Brasileira de Sementes, v.25, n.2, p.70-76, 2003. http://www.scielo.br/pdf/rbs/v25n2/19651.pdf 
KAPPES, C.; ARF, O.; FERREIRA, J.P.; PORTUGAL, J.R.; ALCALDE, A.M.; ARF, M.V.; VILELA, R.G. Qualidade fisiológica de sementes e crescimento de plântulas de feijoeiro, em função de aplicações de paraquat em pré-colheita. Pesquisa Agropecuária Tropical, v.42, n.1, p.9-18, 2012. http://www.scielo.br/pdf/pat/v42n1/02.pdf

KIRCHNER, J.H.; MATTIONI, N.M.; ROBAINA, A.D.; PEITER, M.X.; BARZOTTO, F.; MEZZOMO, W. Qualidade física, fisiológica e danos mecânicos nas etapas do beneficiamento de sementes de soja. Tecnologia \& Ciência Agropecuária, v.8, n.2, p.15-20, 2014. http://www.emepa.org.br/ revista/volumes/tca_v8_n2_jun/tca8210.pdf

KOLCHINSKI, E.M.; SCHUCH, L.O.B.; PESKE, S.T. Crescimento inicial de soja em função do vigor de sementes. Revista Brasileira de Agrociência, v.12, n.2, p.163-166, 2006. http://www.scielo.br/scielo.php?script=sci nlinks\&ref $=000078 \&$ pid $=$ S0101-3122200900010001600009\&lng=en

KRZYZANOWSKI, F.C. Teste de comprimento de raiz de plântulas de soja. Informativo Abrates, v.2, p.11-14, 1991.

KRZYZANOWSKI, F.C.; VIEIRA, R.D.; FRANÇA-NETO, J.B. Vigor de sementes: conceitos e testes. Londrina: ABRATES, 1999. 218 p.

MACHADO, A.; CONCEIÇÃO, A.R. Programa estatístico WinStat: sistema de análise estatística para Windows, 2003. http://minerva.ufpel.edu. br/ amachado/WinStat.EXE

MARCOS-FILHO, J. Fisiologia de sementes de plantas cultivadas. Piracicaba: FEALQ, 2005. 495p.

MARCOS - FILHO, J. Importância do potencial fisiológico da semente de soja. Informativo ABRATES, v.23, p.21-23, 2013.

MERTZ, L.M.; HENNING, F.A.; MAIA, M.S.; MENEGHELLO, G.E.; HENRIQUES, A.; MADAIL, R. Qualidade fisiológica e sanitária de sementes de feijão miúdo beneficiadas em mesa gravitacional. Revista Brasileira de Sementes, v.29, n.3, p.1-8, 2007. http://www.scielo.br/scielo.php?script=sci arttext\&pid=s0101-31222007000300001

NAKAGAWA, J. Testes de vigor baseados no desempenho das plântulas. In: KRZYZANOWSKI, F.C.; VIEIRA, R.D.; FRANÇA-NETO, J.B. (Eds.) Vigor de sementes: conceitos e testes. Londrina: ABRATES, v.2, p.1-24, 1999.

PEREIRA, C.E.; ALBUQUERQUE, K.S.; OLIVEIRA, J.A. Qualidade física e fisiológica de sementes de arroz ao longo da linha de beneficiamento. Semina: Ciências Agrárias, v.33, n.1, p.2995-3002, 2012. http://www.uel.br/ revistas/uel/index.php/semagrarias/article/view/8097/11793
PINTO, T.L.F.; MONDO, V.H.V.; GOMES-JÚNIOR, F.G.; CICERO, S.M Análise de imagens na avaliação de danos mecânicos em sementes de soja Pesquisa Agropecuária Tropical, v.42, n.3, p.310-316, 2012. http://www. revistas.ufg.br/index.php/pat/article/view/18847

QUEIROZ，J.R.; MATA，M.E.R.M.C; DUARTE，M.E.M.; FARIAS，P. A.; ALMEIDA, R.D.; CAVALCANTI, R.F.R.R.M. Simulação de danos mecânicos em feijão carioca durante o processo de beneficiamento. Revista Brasileira de Produtos Agroindustriais, v.14, p.435-444, 2012. http://www. deag.ufcg.edu.br/rbpa/rev14e/Art14E2.pdf

SANTOS, F.; MEDINA, P.F.; LOURENÇÃO, A.L.; PARISI, J.J.D.; GODOY, I.J. Qualidade de sementes de amendoim armazenadas no estado de São Paulo. Bragantia, v.72, n.3, p.310-317, 2013. http://www.scielo.br/ pdf/brag/v72n3/14.pdf

SCHEEREN, B.R.; PESKE, S.T.; SCHUCH, L.O.B.; BARROS, A.C.A Qualidade fisiológica e produtividade de sementes de soja. Revista Brasileira de Sementes, v.32, p.35-41, 2010. http://www.scielo.br/pdf/rbs/v32n3/v32n3a04.pdf

SILVA, J.B.; LAZARINI, E.; SÁ, M.E. Comportamento de sementes de cultivares de soja, submetidos a diferentes períodos de envelhecimento acelerado. Bioscience Journal, v.26, p.755-762, 2010. http://www.seer.ufu. br/index.php/biosciencejournal/article/view/7187

SILVA， R.P.; TEIXEIRA， I.R.; DEVILLA， I.A.; REZENDE， R.C.; SILVA, G.C. Qualidade fisiológica de sementes de soja (Glycine max L.) durante o beneficiamento. Semina: Ciências Agrárias, v.32, n.4, p.12191230, 2011. http://www.uel.br/revistas/uel/index.php/semagrarias/article/ view/4731/8887

TERASAWA, J.M.; PANOBIANCO, M.; POSSAMAI, E.; KOEHLER, H.S. Antecipação da colheita na qualidade fisiológica de sementes de soja. Bragantia, v.68, p.765-773, 2009. http://www.scielo.br/scielo php?pid=S0006-87052009000300025\&script=sci_arttext

TOLEDO, M.Z.; FONSECA, N.R.; CESAR, M.L.; SORATTO, R.P.; CAVARIANI, C.; CRUSCIOL, C.A.C. Qualidade fisiológica e armazenamento de sementes de feijão em função da aplicação tardia de nitrogênio em cobertura. Pesquisa Agropecuária Tropical, v.39, n.2, p.124133, 2009. http://www.revistas.ufg.br/index.php/pat/article/view/3486

TUNES, L.M.; BARROS, A.C.S.A.; BADINELLI, P.G.; GARCIA, D.C Armazenabilidade de sementes de cevada colhidas em diferentes épocas. Bioscience Journal, v.26, n.3, p.403-412, 2010. file:///C:/Users/cris/ Desktop/7121-29761-1-PB.pdf 